\title{
Measuring the performance of perennial alfalfa with drought tolerance indices
}

\author{
Djamal Bellague ${ }^{1,2 *}$, Mahfoud M'Hammedi-Bouzina ${ }^{2}$, and Aïssa Abdelguerfi ${ }^{3}$
}

\section{ABSTRACT}

Drought is one of the abiotic stresses that reduces agricultural production in the Mediterranean basin. The selection of crop varieties with performance adapted to water stress has been the subject of numerous studies. In this context, 16 alfalfa (Medicago sativa L.) cultivars from different origins (Algeria, Australia, France, Italy, Morocco, Tunisia, and the United States) were studied under two water regimes (irrigated and rainfed) in the Lower-Cheliff plain of Algeria. The trials focused on the performance of these cultivars according to eight drought tolerance indices. To achieve this, DM yields and water use efficiency (WUE) of a 2-yr experimental study were used. Results showed a regression in mean yields from the third to the fourth year with stress indices of 0.29 and 0.88 , respectively. The study of correlations showed that DM yields were well correlated to mean production (MP) and the stress tolerance index (STI). For the two trials and based on yield and STI index, 'Mamuntanas', 'Ameristand 801S', 'Erfoud 1' and 'Ecotipo siciliano' had the best performance. However, 'Coussouls', 'Magali', 'Prosementi', 'Africaine', and 'Gabès-2355' performed poorly. Discriminant function analysis showed that the variables that discriminated in the cultivar groups for yield in the irrigated trial were modified STI, WUE, and the superiority index (Pi). The ANOVA test of cumulative yield and the regression rate confirmed that under environmental conditions similar to the LowerCheliff plain, 'Mamuntanas', 'Ameristand 801S', 'Erfoud 1', and 'Ecotipo siciliano' were perennial and performed under irrigated conditions while 'Erfoud 1' performed in the rainfed trial.

Key words: Drought index, Lower-Cheliff, Medicago sativa, performance, yield.

${ }^{1}$ National Institute of Agronomic Research of Algeria, 2 rue les frères OUADEK BP 200, Hassan Badi, El-Harrach (16200), Algiers, Algeria. *Corresponding author (bellague@yahoo.fr).

${ }^{2}$ University Hassiba Benbouali of Chlef, Laboratory of Local Natural Bio-Resources, Hay Salem, Route Nationale N 19, Chlef (02000), Algeria.

${ }^{3}$ National Higher School of Agronomy, Avenue Hassan Badi, El Harrach 16200, Algiers, Algeria.

Received: 9 November 2015.

Accepted: 29 March 2016.

doi:10.4067/S0718-58392016000300003

\section{INTRODUCTION}

Abiotic stresses are the main factors that reduce production. Drought is the most significant because it limits agricultural plant production in arid and semi-arid areas (Mollasadeghi et al., 2011; Hussain et al., 2012). It can be defined as a temporary rainfall deficit that causes more or less significant yield losses. It is important to minimize losses due to stress to ensure production stability (Öztürk et al., 2014). When drought sets in, resistant plants, such as alfalfa (Medicago sativa L.), reduce their aerial parts (Durand, 2007); this limits the leaf area index and produced biomass decreases as a consequence.

Drought is a phenomenon of great magnitude. It is random in time and space and is usually combined with high temperatures (Itier and Seguin, 2007). It has an intense effect when associated with biotic stress and inappropriate soil characteristics (Moghaddam et al., 2012). Depending on its intensity and severity, it can affect several sensitive and strategic sectors such as agriculture. It can jeopardize food security if farmers abandon their lands to look for other more lucrative activities.

In Algeria, drought is considered as the main cause of a significant drop in yields. To cope with drought and protect themselves from it, farmers immediately turn to irrigation. Water is a vital resource limited in time and space whether we consider its quantity and/or quality. Therefore, it is imperative to conserve it. This can be done in several water-consuming areas. In agriculture, the selection of efficient crop varieties adapted to drought conditions has been the subject of numerous studies.

Alfalfa, a very productive perennial forage species, has deep roots and is considered a drought-adapted species (Lemaire, 2006). It improves soil $\mathrm{N}$ fertility (Latrach et al., 2014), protects soils that are vulnerable to wind and water erosion (Abdelguerfi and Abdelguerfi-Laouar, 2002), and can improve the sustainability of crop-livestock systems in the Mediterranean basin (Annicchiarico et al., 2011).

To select increasingly efficient cultivars, some researchers use favorable conditions while others use stress conditions. A third group believes that trials under stress and non-stress conditions are the starting point in identifying cultivars able to cope with unpredictable drought (Sio-Se Mardeh et al., 2006).

Sensitivity to drought is often measured in terms of lower yields under stress conditions. Quantifying the degree of tolerance and/ or resistance of crops to drought stress requires several indices. Rosielle and Hamblin (1981) calculated the tolerance index (TOL), which represents the difference in yield under stress and non-stress conditions taking into account mean production (MP). Fernandez (1992) used the stress tolerance index (STI) and the geometric 
mean production index (GMP). In 2003, Farshadfar and Sutka suggested the modified stress tolerance index (MSTI), which is STI multiplied by a correction factor $(\mathrm{Ki})$ for stress and non-stress conditions, Clarke et al. (1992) suggested the superiority index (Pi) and Moosavi et al. (2007) developed the abiotic tolerance index (ATI).

These indices were used to assess the performance of 16 perennial alfalfa cultivars under rainfed and irrigated conditions in a semi-arid to arid Mediterranean region.

\section{MATERIALS AND METHODS}

\section{Experimental site and climatic conditions}

According to the Köppen classification based on precipitation and temperature, the climate of our study site is Mediterranean (code: Csa), that is, warm temperate with a dry and hot summer (Hufty, 2001).

Our experiment took place at the station of the National Institute of Agronomic Research of Algeria (INRAA) at Hmadna $\left(35^{\circ} 54^{\prime} \mathrm{N}, 00^{\circ} 54^{\prime} \mathrm{E}\right.$; $48 \mathrm{~m}$ a.s.l.), which is characterized by a semi-arid to arid climate. Climate data recorded during the $4 \mathrm{yr}$ of the PERMED project (Improvement of native perennial forage plants for sustainability of Mediterranean farming systems) showed a progression in rainfall from the first year to the third year and then a regression in the fourth year. Compared to the first year $(242.70 \mathrm{~mm})$, there was an increase of $34.32 \%$ and $38.85 \%$, respectively, for the second and third years and a decrease of $6.43 \%$ in the fourth year. Monthly rainfall was normal, but values were low in the last year of production. Average monthly temperatures for the $4 \mathrm{yr}$ of production were very similar and ranged from $19.52{ }^{\circ} \mathrm{C}$ to $19.79{ }^{\circ} \mathrm{C}$. Monthly temperature and rainfall distribution is shown in Figure 1.

The climate requirement defined by evapotranspiration was calculated by the Penman-Monteith formula and depended on the climatic parameters recorded at the agrometeorological station of Hmadna; its value exceeded $1200 \mathrm{~mm}$. The soil physicochemical analysis of the experimental site revealed a silty clay texture ( $47.19 \%$ clay, $42.11 \%$ silt, and $10.7 \%$ sand), $\mathrm{pH}$ of 7.95, an electrical conductivity of the saturated paste of $3.45 \mathrm{dS} \mathrm{m}^{-1}$, and a mean bulk density of 1.48 . According to McDonald et al. (1990) and the WRB (2015) classification system, the soil is a Vertisol. Boulaine (1957) presents it as an original alluvial saline soil.

\section{Plant material and experimental design}

Sixteen efficient cultivars have been selected from several countries: One cultivar from Algeria ('Tamantit'), two from Australia ('Sardi 10' and 'Siriver'), three from Italy ('Ecotipo siciliano', 'Prosementi' and 'Mamuntanas'), three from France ('Melissa', 'Magali', and 'Coussouls'), four from Morocco ('Africaine', 'Erfoud 1', 'Demnat 203', and 'Rich 2'), one from Tunisia ('Gabès- 2355'), and two from the United States ('ABT 805' and 'Ameristand $801 S^{\prime}$ '). These cultivars were provided by the project (PERMED, 2004).

This experiment was carried out under two water regime conditions, a rainfed trial and a trial irrigated to maximum evapotranspiration (MET).

The experimental design adopted for both trials was a randomized complete block design with four replicates. Each elementary plot area was $5 \mathrm{~m}^{2}(200 \mathrm{~cm} \times 250 \mathrm{~cm}, 10$ rows with $20 \mathrm{~cm}$ spacing).

Sprinkler irrigation for the irrigated trial occurred weekly. Water needs were estimated by the PenmanMonteith formula, MET $=0.8$ mean reference evapotranspiration $\left(\mathrm{ET}_{0}\right)$ calculated over a $13-\mathrm{yr}$ period. The quantity of water effectively supplied to each plot is the difference between the water needs and precipitation. Irrigation started after the first rainfall events and stopped for 9 wk starting late June.

Cutting (5 $\mathrm{cm}$ above ground) was initiated to obtain yield in $\mathrm{tha}^{-1}$ (DM after oven-drying at $80{ }^{\circ} \mathrm{C}$ for $48 \mathrm{~h}$ ) when $75 \%$ of the plants in the elementary plots reached a height of 30 to $35 \mathrm{~cm}$ in the winter season or when regrowth appeared at the base of the plant as well as at $50 \%$ flowering of $75 \%$ of the plots in the spring season.

Figure 1. Temperature and rainfall monthly distribution for the $4 \mathrm{yr}$ of the PERMED project.

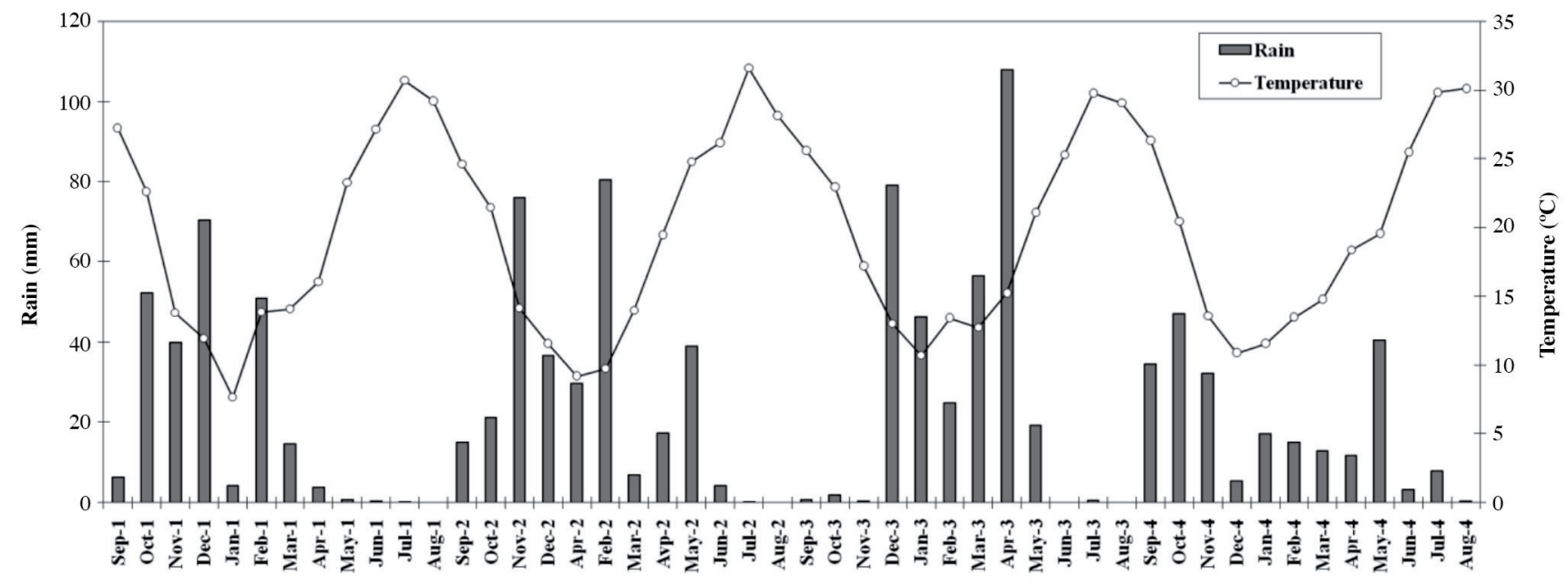




\section{Yield, water use efficiency (WUE), and calculation of indices}

The yield of each elementary plot was estimated with the production of the six middle rows $2 \mathrm{~m}$ in length, which represented a $2.40 \mathrm{~m}^{2}$ area. Thus, WUE was calculated as the ratio between yield and the corresponding water consumption (Zwart and Bastiaanssen, 2004) by taking into account DM yield and evapotranspiration (ET); it was expressed in $\mathrm{kg} \mathrm{m}^{-3}$ according to the formula:

\section{WUE $\left(\mathrm{kg} \mathrm{DM} \mathrm{m}^{-3}\right)=$ Yield DM/ET}

After each cutting, the hydraulic profile (1 m depth) was measured with a previously calibrated CPN503 neutron probe (CPN International, Concord, California, USA); the difference in water storage between the profiles of two successive cuttings, rainfall, and irrigation were quantified to estimate water consumption by the simplified water balance equation.

The eight drought tolerance indices included tolerance (TOL), which is the difference between yield in irrigated and rainfed trials, and its lowest value corresponded to the cultivar that behaved in the same way under stress and nonstress conditions, mean production (MP), harmonic mean (HM), geometric mean production (GMP), stress tolerance index (STI), modified stress tolerance index (MSTI), superiority index $(\mathrm{Pi})$, and abiotic tolerance index (ATI) that were calculated with the formulas in Table 1.

In the Clarke et al. (1992) formula, Xij represents the yield of each cultivar $(i)$ under conditions $j$ and $M j$ represents maximum yield under conditions $j$. In the present study, it represents the number of cultivars ( $i=1$ to 16$), j$ is the number of trials $(j=1$ for the rainfed trail and $j=2$ for the irrigated trial), and $n$ represents the number of environments $(n=2)$.

High values of drought tolerance/resistance indices and yields (MP, HM, GMP, STI, $\mathrm{K}_{1} \mathrm{STI}, \mathrm{K}_{2} \mathrm{STI}$, ATI, Yp, and Ys) were given to the best-performing cultivars and assigned rank
1. However, low values of TOL and Pi indices corresponded to the best-performing cultivars and were assigned rank 1 .

Based on the values of Yp, Ys, and STI, Fernandez (1992) classified cultivars into four groups according to their performance under stress and non-stress conditions. Group A included cultivars that expressed uniform superiority under both stress and non-stress conditions. Group B included cultivars that were only favorable under non-stress conditions. Group C included cultivars that gave relatively high yields under stress conditions. Finally, group D included cultivars that performed poorly under both stress and nonstress conditions.

\section{Survival}

Alfalfa sensitivity to yield losses becomes important depending on plant age. Mauriès (1994) noted that alfalfa attains its maximum yield in the third year of production and tends to decrease beyond that. Plant density (PD), which was measured in each year of the experiment, is an index that provides information about production and survival over time. Sustainability can be defined as the regression rate $(\mathrm{Rr})$ of plant density.

The regression rate is the difference between plant density in two successive years compared to initial plant density. It is calculated by the following formula:

$$
R r=\frac{P D_{\mathrm{i}-1}-P D_{i}}{P D_{\mathrm{i}-1}} * 100
$$

where $\operatorname{Rr}(\%)$ is the regression rate; $P D_{i-1}$ (plant $\mathrm{m}^{-2}$ ) is plant density for year $i-1$ (third year of production); $P D_{i}$ (plant $\mathrm{m}^{-2}$ ) is plant density the year $i$ order (fourth year production).

\section{Statistical analyses}

The statistical study focused on correlations between the indices and DM yield under two stress and non-stress conditions (rainfed and irrigated, respectively); the study of discriminant function analysis (DFA)and ANOVA with

Table 1. Methods to calculate drought tolerance indices*.

\begin{tabular}{lll}
\hline$N^{\circ}$ & \multicolumn{1}{c}{ Formulas } & References \\
\hline 1 & $T O L=Y p-Y s$ & Rosielle and Hamblin (1981) \\
$3 P=\frac{Y p+Y s}{2}$ & Rosielle and Hamblin (1981) \\
$4 M=2 * \frac{Y p * Y s}{Y p+Y S}$ & Chakherchaman et al. (2009) \\
5 & $G M P=\sqrt{Y p * Y s}$ & Fernandez (1992) \\
6 & $S T I=\frac{(Y p+Y s)}{\bar{Y} p^{2}}$ & Fernandez (1992) \\
7 & $M S T I=K_{i} S T I \quad K_{1}=\left(\frac{Y p}{\bar{Y} p}\right)^{2} ; K_{2}=\left(\frac{Y S}{\bar{Y} s}\right)^{2}$ & Farshadfar and Sutka (2003) \\
8 & $P i=\sum_{j=1}^{n} \frac{(X i j-M j)^{2}}{2 n}$ & Lin and Binns (1988), \\
Clarke et al. (1992)
\end{tabular}

*Description under stress and non-stress (rainfed and irrigated, respectively) conditions: yield for each cultivar (Ys and Yp), general mean yield ( $\overline{y s}$ and $\bar{y} p$, and correction coefficients $\left(\mathrm{K}_{2}\right.$ and $\left.\mathrm{K}_{1}\right)$. 
the test of least significant difference (LSD, $\mathrm{p}<0.05$ ) were performed with the XLSTAT-2014 software (Addinsoft, Brooklyn, New York, USA).

\section{RESULTS AND DISCUSSION}

\section{Comparison of cultivars with resistance/ tolerance indices}

Mean yields from the third to the fourth year decreased. Mean yields recorded in the third year were 6.05 and $8.49 \mathrm{t} \mathrm{DM} \mathrm{ha}^{-1}$ for the rainfed and irrigated trials, respectively, and with a stress index (SI) of 0.29. Fourth year yields were $0.77 \mathrm{t} \mathrm{DM} \mathrm{ha}^{-1}$ under rainfed and $6.66 \mathrm{t} \mathrm{DM} \mathrm{ha-1} \mathrm{under} \mathrm{irrigated} \mathrm{conditions} \mathrm{with} \mathrm{an}$ SI of 0.88 . The highest SI values indicated greater intensity (SI ranges from 0 to 1 ). Thus, the resulting index reflected drought intensity during the fourth year of production. The correlation coefficient between rainfed and irrigated yields decreased from $r=0.61$ in the third year to $r=0.53$ in the fourth year.

Akcura and Ceri (2011) indicate that the cultivars with the highest STI have the highest yields under stress and nonstress conditions.

\section{Third year of production}

The STI showed that 'Ameristand 801S', 'Mamuntanas', 'Ecotipo siciliano', and 'Erfoud 1' displayed high tolerance to drought and were more profitable. They had mean yields from 9.18 to $10.95 \mathrm{t} \mathrm{DM} \mathrm{ha}^{-1}$ in the irrigated trial and from 6.95 to 8.34 t DM ha $^{-1}$ in the rainfed trial; STI was between 0.94 and 1.15. 'Africaine', 'Tamantit', 'Prosementi', and 'Magali' were less drought-tolerant and their STI was less than 0.51 .

Harmonic mean (HM), MP, and GMP had substantially the same values. They allowed classifying the most profitable cultivars, which were, in descending order, 'Mamuntanas', 'Ameristand 801S', 'Erfoud 1', and 'Ecotipo siciliano' with values of 9.11, 8.44, 8.35, and 8.24 t DM ha ${ }^{-1}$, respectively. On the other hand, 'Magali', 'Prosementi', 'Tamantit', and 'Africaine' were among the least productive with values varying between 5.66 and $6.03 \mathrm{t} \mathrm{DM} \mathrm{ha-1}$.

'Rich 2' had a TOL of 0.13 and low yield in the irrigated trial, which is less than the overall mean, and higher yield in the rainfed trial. Combining irrigated yields with low TOL values, the best-performing cultivars had high yields under irrigated conditions and higher than average yields under stress conditions, which was the case for 'Mamuntanas' and 'Erfoud 1'.

The best-performing cultivars usually had the highest yields in both trials with $\mathrm{K}_{1} \mathrm{STI}$ and $\mathrm{K}_{2} \mathrm{STI}$ values that exceeded the unit. Regarding $\mathrm{K}_{1} \mathrm{STI}$, the best-performing cultivars are 'Ameristand 801S', 'Mamuntanas', 'Ecotipo siciliano', and 'Erfoud 1'with values of 1.64, 1.58, 1.24, and 1.13, respectively. On the other hand, the most successful cultivars were 'Mamuntanas', 'Erfoud 1', 'Ecotipo siciliano', and 'Ameristand $801 \mathrm{~S}$ ' with $\mathrm{K}_{2} \mathrm{STI}$ values of 2.19, 1.53 , 1.24 , and 1.14, respectively. Values for other cultivars are displayed in Table 2.

\section{Fourth year of production}

Irrigated trial yields ranged from 3.82 to $8.59 \mathrm{t} \mathrm{DM} \mathrm{ha}^{-1}$ and 0.33 to $1.26 \mathrm{t} \mathrm{DM} \mathrm{ha}^{-1}$ in the rainfed trial. The most profitable irrigated cultivars, in descending order, were 'Ameristand 801S' (8.59 t DM ha-1), 'Ecotipo siciliano’ (8.45 t DM ha'), 'Sardi 10' (7.90 t DM ha-1), 'Erfoud 1' (7.88 t DM ha-1), and 'Demnat 203' (7.79 t DM ha-1). However, the most profitable cultivars in the rainfed trial were 'Sardi 10' (1.26 $\left.\mathrm{t} \mathrm{DM} \mathrm{ha}^{-1}\right)$, 'Mamuntanas' (1.24 t DM ha $\left.{ }^{-1}\right)$, 'Erfoud 1' (1.20 t DM ha $\left.{ }^{-1}\right)$, and 'Melissa' (1.14 t DM ha' ${ }^{-1}$ ).

The TOL values were high; the difference between the two yields became apparent. On the average, this difference exceeded $50 \%$ of the yield in the irrigated trial. Recorded

Table 2. Mean yields and resistance/tolerance indices in the third year of production.

\begin{tabular}{|c|c|c|c|c|c|c|c|c|c|c|c|c|c|}
\hline Cultivars & Yp & Ys & TOL & HM & MP & GMP & STI & $\mathrm{K}_{1} \mathrm{STI}$ & $\mathrm{K}_{2} \mathrm{STI}$ & $\mathrm{Pi}$ & ATI & WUEp & WUEs \\
\hline Ecotipo siciliano & 9.75 & 6.95 & 2.80 & 8.12 & 8.35 & 8.24 & 0.94 & 1.24 & 1.24 & 0.84 & 16.41 & 2.13 & 2.13 \\
\hline Prosementi & 7.17 & 4.95 & 2.22 & 5.86 & 6.06 & 5.96 & 0.49 & 0.35 & 0.33 & 6.44 & 9.43 & 1.61 & 1.47 \\
\hline ABT 805 & 8.97 & 5.82 & 3.16 & 7.06 & 7.40 & 7.22 & 0.72 & 0.81 & 0.67 & 2.57 & 16.25 & 1.98 & 1.93 \\
\hline Ameristand 801S & 10.95 & 6.51 & 4.44 & 8.16 & 8.73 & 8.44 & 0.99 & 1.64 & 1.14 & 0.84 & 26.69 & 2.44 & 2.02 \\
\hline Mamuntanas & 9.95 & 8.34 & 1.61 & 9.08 & 9.15 & 9.11 & 1.15 & 1.58 & 2.19 & 0.25 & 10.45 & 2.14 & 2.16 \\
\hline Tamantit & 7.64 & 4.50 & 3.14 & 5.67 & 6.07 & 5.87 & 0.48 & 0.39 & 0.26 & 6.42 & 13.13 & 1.77 & 1.46 \\
\hline Sardi 10 & 9.09 & 6.58 & 2.52 & 7.63 & 7.84 & 7.73 & 0.83 & 0.95 & 0.98 & 1.64 & 13.86 & 2.08 & 2.02 \\
\hline Siriver & 9.00 & 6.31 & 2.69 & 7.42 & 7.66 & 7.54 & 0.79 & 0.89 & 0.86 & 1.98 & 14.46 & 2.02 & 1.81 \\
\hline Africaine & 6.82 & 4.70 & 2.12 & 5.56 & 5.76 & 5.66 & 0.44 & 0.29 & 0.27 & 7.59 & 8.54 & 1.62 & 1.40 \\
\hline Gabès-2355 & 8.05 & 5.07 & 3.43 & 6.35 & 6.78 & 6.56 & 0.6 & 0.60 & 0.42 & 4.17 & 16.02 & 2.05 & 1.69 \\
\hline Magali & 6.92 & 5.25 & 1.68 & 5.97 & 6.09 & 6.03 & 0.50 & 0.33 & 0.38 & 6.44 & 7.19 & 1.60 & 1.65 \\
\hline Melissa & 8.37 & 6.81 & 1.56 & 7.51 & 7.59 & 7.55 & 0.79 & 0.77 & 1.00 & 2.24 & 8.41 & 1.86 & 2.13 \\
\hline Coussouls & 8.02 & 5.46 & 2.57 & 6.50 & 6.74 & 6.62 & 0.61 & 0.54 & 0.49 & 4.22 & 12.09 & 1.76 & 1.72 \\
\hline Rich 2 & 7.18 & 7.05 & 0.13 & 7.11 & 7.11 & 7.11 & 0.70 & 0.50 & 0.95 & 3.97 & 0.64 & 1.56 & 2.25 \\
\hline Erfoud 1 & 9.18 & 7.60 & 1.58 & 8.32 & 8.39 & 8.35 & 0.97 & 1.13 & 1.53 & 0.92 & 9.38 & 2.06 & 2.19 \\
\hline Demnat 203 & 8.37 & 4.88 & 3.49 & 6.17 & 6.62 & 6.39 & 0.57 & 0.55 & 0.37 & 4.66 & 15.87 & 1.96 & 1.46 \\
\hline Maximum & 10.95 & 8.34 & 4.44 & 9.08 & 9.15 & 9.11 & 1.15 & 1.64 & 2.19 & 7.59 & 26.69 & 2.44 & 2.25 \\
\hline Minimum & 6.82 & 4.50 & 0.13 & 5.56 & 5.76 & 5.66 & 0.44 & 0.29 & 0.26 & 0.25 & 0.64 & 1.56 & 1.40 \\
\hline Mean & 8.49 & 6.05 & 2.45 & 7.03 & 7.27 & 7.15 & 0.72 & 0.78 & 0.82 & 3.45 & 12.43 & 1.92 & 1.84 \\
\hline
\end{tabular}

Yp: irrigated DM yield; Ys: rainfed DM yield; TOL: tolerance; HM: harmonic mean; MP: mean production; GMP: geometric mean production; STI: stress tolerance index; $\mathrm{K}_{1} \mathrm{STI}$ : irrigated modified stress tolerance index; $\mathrm{K}_{2} \mathrm{STI}$ : rainfed modified stress tolerance index; Pi: superiority index; ATI: abiotic tolerance index; WUEp: irrigated water use efficiency; WUEs: rainfed water use efficiency. 
TOLs were between 3.49 ('Magali') and 7.86 ('Ecotipo siciliano').

The three types of means (harmonic, arithmetic, and geometric) have different values. The MPs were high but HMs remained low. The MP allowed classifying the cultivars according to their yields, that is, 'Ameristand 801S' (4.70 t DM ha-1), 'Sardi 10' (4.58 t DM ha ${ }^{-1}$ ), 'Erfoud 1' (4.54 t DM ha-1), 'Ecotipo siciliano' (4.52 t DM ha $\left.{ }^{-1}\right)$, 'Melissa' (4.41 t DM ha ${ }^{-1}$ ), and 'Mamuntanas' (4.38 t DM ha-1).

The STI values did not exceed 0.23. In general, values higher than 0.15 corresponded to higher yields in the irrigated and rainfed trials. Low STI values, as well as $\mathrm{K}_{1}$ and $\mathrm{K}_{2}$ coefficients linked to lower than average yields, led to lower $\mathrm{K}_{1} \mathrm{STI}$ and $\mathrm{K}_{2} \mathrm{STI}$ values (Table 3 ).

In Tunisia, Hayek et al. (2008) subjected the same cultivars to summer water stress by stopping irrigation for 43,56 , and $65 \mathrm{~d}$ in the first, second, and third years of production, respectively. Cumulative DM yield showed that 'Ecotipo siciliano', 'Ameristand 801S', and 'Mamuntanas' were among the most productive whereas 'Tamantit' and 'Africaine' were the least productive.

Benabderrahim et al. (2015) conducted trials with the same cultivars under two irrigation conditions. The first was normally irrigated to the potential evapotranspiration of the crop and the second was conducted under water stress, which was applied by stopping irrigation during $8 \mathrm{wk}$ in summer. Results showed that 'Ameristand 801S' exhibited high forage yield, which is similar to our results.

Farissi et al. (2013) measured the effect of three water deficit levels in terms of field capacity (FC) (25\% FC, $50 \%$ FC, and 75\% FC) on agro-physiological and biochemical properties of four perennial alfalfa populations of Moroccan origin. They found that DM reduction was very high compared with the optimal treatment $(75 \% \mathrm{FC})$ and production loss increased with water shortage severity. This confirms the results we found in the fourth year. The drop in output between the two trials reached $88.44 \%$, that is, a difference of $5.89 \mathrm{t} \mathrm{DM} \mathrm{ha}^{-1}$.

The correlation coefficient between yields in the rainfed and irrigated trials from the third to fourth year of production was inversely proportional to the SI. This is confirmed in the study by Moghaddam et al. (2012) in Vienna, Austria, about drought tolerance indices for selecting perennial alfalfa genotypes. The correlation coefficient between yields in the irrigated and rainfed trials increased from the first to the second year with a reduced SI (Tables 2 and 3).

\section{Correlation analysis}

Yield under rainfed conditions (Ys) was well correlated with all indices, except for TOL, ATI, and WUEp in the third year and only TOL in the fourth year. Yield in the irrigated trial (Yp) was well correlated with all indices except for TOL in the third year of production.

The TOL index was only correlated with ATI and WUEp in the third year of production. However, in the fourth year of production, it was correlated with all indices, except for $\mathrm{HM}, \mathrm{K}_{2} \mathrm{STI}$, and WUEs. The Pi index was well correlated and inversely proportional with the other indices. The ATI was similarly well correlated in both the fourth and third years of production. The WUEp was significantly correlated with WUEs in the fourth year but not in the third year. All the indices in the fourth year were generally well correlated, except for the relationship between TOL and HM, Ys, and WUEs (Table 4).

The correlations between yields (Yp and Ys) and tolerance/ resistance to drought indices, except for TOL and ATI (third year of production), were confirmed by the research studies conducted on wheat genotypes in Ilam, Iran (Dehbalaei et al., 2013), on the segregation of rice populations by tolerance

Table 3. Mean yields and resistance/tolerance indices in the third year of production.

\begin{tabular}{|c|c|c|c|c|c|c|c|c|c|c|c|c|c|}
\hline Cultivars & Yp & Ys & TOL & HM & $\mathrm{MP}$ & GMP & STI & $\mathrm{K}_{1} \mathrm{STI}$ & $\mathrm{K}_{2} \mathrm{STI}$ & $\mathrm{Pi}$ & ATI & WUEp & WUEs \\
\hline Ecotipo siciliano & 8.45 & 0.59 & 7.86 & 1.11 & 4.52 & 2.24 & 0.11 & 0.18 & 0.07 & 0.12 & 2.05 & 0.86 & 0.29 \\
\hline Prosementi & 4.75 & 0.47 & 4.28 & 0.86 & 2.61 & 1.49 & 0.05 & 0.03 & 0.02 & 3.85 & 0.74 & 0.49 & 0.24 \\
\hline ABT 805 & 6.14 & 0.81 & 5.33 & 1.43 & 3.48 & 2.23 & 0.11 & 0.10 & 0.12 & 1.55 & 1.38 & 0.63 & 0.41 \\
\hline Ameristand $801 \mathrm{~S}$ & 8.59 & 0.80 & 7.79 & 1.46 & 4.70 & 2.62 & 0.16 & 0.26 & 0.17 & 0.05 & 2.38 & 0.88 & 0.42 \\
\hline Mamuntanas & 7.52 & 1.24 & 6.28 & 2.13 & 4.38 & 3.06 & 0.21 & 0.27 & 0.54 & 0.29 & 2.23 & 0.77 & 0.59 \\
\hline Tamantit & 7.21 & 0.68 & 6.53 & 1.24 & 3.94 & 2.21 & 0.11 & 0.13 & 0.08 & 0.56 & 1.68 & 0.74 & 0.34 \\
\hline Sardi 10 & 7.90 & 1.26 & 6.64 & 2.18 & 4.58 & 3.16 & 0.23 & 0.32 & 0.60 & 0.12 & 2.44 & 0.81 & 0.69 \\
\hline Siriver & 6.63 & 0.71 & 5.92 & 1.28 & 3.67 & 2.17 & 0.11 & 0.11 & 0.09 & 1.04 & 1.49 & 0.68 & 0.39 \\
\hline Africaine & 4.89 & 0.75 & 4.14 & 1.30 & 2.82 & 1.91 & 0.08 & 0.04 & 0.08 & 3.49 & 0.92 & 0.50 & 0.36 \\
\hline Gabès-2355 & 6.50 & 0.63 & 5.87 & 1.15 & 3.57 & 2.03 & 0.09 & 0.09 & 0.06 & 1.19 & 1.39 & 0.66 & 0.25 \\
\hline Magali & 3.82 & 0.33 & 3.49 & 0.61 & 2.08 & 1.12 & 0.03 & 0.01 & 0.01 & 5.90 & 0.46 & 0.39 & 0.17 \\
\hline Melissa & 7.69 & 1.14 & 6.55 & 1.98 & 4.41 & 2.96 & 0.2 & 0.26 & 0.43 & 0.21 & 2.26 & 0.79 & 0.57 \\
\hline Coussouls & 6.24 & 0.49 & 5.75 & 0.91 & 3.37 & 1.75 & 0.07 & 0.06 & 0.03 & 1.53 & 1.17 & 0.64 & 0.29 \\
\hline Rich 2 & 4.49 & 0.72 & 3.76 & 1.25 & 2.61 & 1.80 & 0.07 & 0.03 & 0.06 & 4.28 & 0.79 & 0.46 & 0.35 \\
\hline Erfoud 1 & 7.88 & 1.20 & 6.68 & 2.08 & 4.54 & 3.08 & 0.21 & 0.30 & 0.51 & 0.13 & 2.39 & 0.81 & 0.63 \\
\hline Demnat 203 & 7.79 & 0.56 & 7.23 & 1.05 & 4.18 & 2.10 & 0.10 & 0.14 & 0.05 & 0.28 & 1.76 & 0.80 & 0.30 \\
\hline Maximum & 8.59 & 1.26 & 7.86 & 2.18 & 4.70 & 3.16 & 0.23 & 0.32 & 0.60 & 5.90 & 2.44 & 0.88 & 0.69 \\
\hline Minimum & 3.82 & 0.33 & 3.49 & 0.61 & 2.08 & 1.12 & 0.03 & 0.01 & 0.01 & 0.05 & 0.46 & 0.39 & 0.17 \\
\hline Mean & 6.66 & 0.77 & 5.88 & 1.38 & 3.72 & 2.25 & 0.12 & 0.14 & 0.18 & 1.54 & 1.60 & 0.68 & 0.39 \\
\hline
\end{tabular}

Yp: irrigated DM yield; Ys: rainfed DM yield; TOL: tolerance; HM: harmonic mean; MP: mean production; GMP: geometric mean production; STI: stress tolerance index; $\mathrm{K}_{1}$ STI: irrigated modified stress tolerance index; $\mathrm{K}_{2}$ STI: rainfed modified stress tolerance index; Pi: superiority index; ATI: abiotic tolerance index; WUEp: irrigated water use efficiency; WUEs: rainfed water use efficiency. 
to drought indices in Rasht, Iran (Rahimi et al., 2013), and tolerance to drought indices of corn in Azerbaijan, Iran (Naghavi et al., 2013). These authors found significant correlations between yields (under rainfed and irrigated conditions) and the STI, GMP, MP, HM, $\mathrm{K}_{1} \mathrm{STI}$, and $\mathrm{K}_{2} \mathrm{STI}$ indices. The study conducted by Boussen et al. (2010) in Tunisia evaluating drought tolerance indices in durum lines showed a good correlation between yields and the TOL, GMP, MP, and STI indices. Another study was conducted by Sareen et al. (2014) in India, who analyzed the interaction between genotype and environment in wheat landraces treated under two abiotic stresses (drought and heat) and found a good correlation between MP and TI (tolerance index) as well as between SI and TOL.

Haffani et al. (2014) in Tunisia measured the effect of four water regimes in terms of field capacity $(100 \% \mathrm{FC}, 80 \% \mathrm{FC}$, $60 \% \mathrm{FC}$, and $40 \% \mathrm{FC}$ ) on the agronomic performance of three vetch species. They found that the STI is proportional to the applied water regime, and DM is affected by the level of water stress in the three years of the experiment.

\section{Representation of three-dimensional dispersion and group analysis}

Fernandez (1992) classified the cultivars according to the yield of both trials (rainfed and irrigated) with the STI. This allowed us to classify 'Mamuntanas', 'Erfoud 1', 'Sardi 10', and 'Ameristand $801 \mathrm{~S}$ ' in group A (most efficient cultivar group) whereas 'Coussouls', 'Magali', 'Prosementi', 'Africaine', and 'Gabès-2355' did not perform and were classified in group D. 'Siriver' and 'ABT 805 ' were grouped near the mean of the two trials while the rest of the cultivars fluctuated between groups (Figure 2).

For the same site, results obtained in the second year of production showed that 'Ameristand 801S' and 'Mamuntanas' were more profitable (Bellague et al., 2008).

Khelifi et al. (2008) consider that 'Ameristand 801S' and 'Mamuntanas' both perform better in irrigated and rainfed trials conducted in a sub-humid region. Bouizgaren et al. (2013) confirmed their performance by combining the yields for each of the abovementioned cultivar in three production seasons (2005-2006, 2006-2007, and 2007-2008) in Morocco.

Regarding the Köppen-Geiger classification (Climatedata, 2016), all the cultivars tested in the PERMED project were in temperate and warm climate areas (Csa, Cfa, and $\mathrm{Cfb}$ ), or a dry desert climate (BWh and BWk). They were characterized by low to nil fall dormancy. Dormancy reported and estimated by Pecetti et al. (2008) according to Teuber et al. (1998), showed that cultivars from Australia, the United States, North Africa (except for the 'Africaine' cultivar), and France ('Melissa') are non-dormant (fall dormancy $\geq$ 8). The cultivars 'Prosementi', 'Coussouls', and 'Africaine' are moderately dormant (fall dormancy $\leq 6$ ) while 'Ecotipo siciliano', 'Mamuntanas', and 'Magali' are fairly dormant (fall dormancy 6 to 8). According to these characteristics, selected cultivars can provide year-round production.

\section{Discriminant function analysis (DFA)}

The overall Wilks' lambda statistic (Rao's approximation) values of 0.052 (third year) and 0.035 (fourth year) at a $5 \%$ level of significance were much lower and very close to zero and far from the unit. Thus, there is significant discrimination among the three groups, which justifies the application of DFA. Individuals related to F1 and F2 of DFA are illustrated in Figure 3. The result of the ascending hierarchical classification based on all studied indices and variables (Figure 4) represents the composition of each homogeneous group for the 2-yr experiment.

A synthesis of the DFA results (third and fourth years of production) performed with an ascending test of canonical functions is shown in Table 5. For Bartlett's statistic, it appears that the two discriminant functions (F1 and F2) for each year are significant at the $5 \%$ level of significance (Table 5). Given the large number of variables in the model, we performed a step-by-step DFA to select only the variables that contributed the most to the discrimination of groups.

Table 4. Correlation coefficients between Yp, Ys, WUE, and resistance/tolerance indices.

\begin{tabular}{|c|c|c|c|c|c|c|c|c|c|c|c|c|c|}
\hline Var. & Yp & Ys & TOL & HM & MP & GMP & STI & $\mathrm{K}_{1} \mathrm{STI}$ & $\mathrm{K}_{2} \mathrm{STI}$ & $\mathrm{Pi}$ & ATI & WUEp & WUEs \\
\hline Yp & & 0.53 & 0.98 & 0.58 & 0.99 & 0.79 & 0.74 & 0.85 & 0.52 & -0.96 & 0.95 & 1.00 & 0.55 \\
\hline Ys & 0.61 & & 0.37 & 1.00 & 0.65 & 0.94 & 0.95 & 0.85 & 0.96 & -0.57 & 0.76 & 0.53 & 0.98 \\
\hline TOL & 0.47 & -0.41 & & 0.42 & 0.95 & 0.67 & 0.61 & 0.75 & 0.37 & -0.94 & 0.88 & 0.98 & 0.40 \\
\hline HM & 0.83 & 0.95 & -0.10 & & 0.69 & 0.95 & 0.97 & 0.87 & 0.95 & -0.61 & 0.79 & 0.58 & 0.98 \\
\hline MP & 0.90 & 0.89 & 0.04 & 0.99 & & 0.87 & 0.83 & 0.91 & 0.63 & -0.96 & 0.98 & 0.99 & 0.66 \\
\hline GMP & 0.87 & 0.93 & -0.03 & 1.00 & 1.00 & & 0.99 & 0.96 & 0.90 & -0.81 & 0.93 & 0.79 & 0.93 \\
\hline STI & 0.86 & 0.92 & -0.03 & 1.00 & 0.99 & 1.00 & & 0.97 & 0.95 & -0.74 & 0.91 & 0.74 & 0.95 \\
\hline $\mathrm{K}_{1} \mathrm{STI}$ & 0.95 & 0.78 & 0.23 & 0.93 & 0.97 & 0.95 & 0.96 & & 0.87 & -0.79 & 0.97 & 0.85 & 0.86 \\
\hline $\mathrm{K}_{2} \mathrm{STI}$ & 0.70 & 0.96 & -0.27 & 0.96 & 0.92 & 0.94 & 0.96 & 0.86 & & -0.52 & 0.75 & 0.52 & 0.95 \\
\hline $\mathrm{Pi}$ & -0.89 & -0.86 & -0.07 & -0.96 & -0.98 & -0.97 & -0.96 & -0.91 & -0.86 & & -0.91 & -0.96 & -0.58 \\
\hline ATI & 0.72 & -0.10 & 0.94 & 0.22 & 0.36 & 0.29 & 0.28 & 0.53 & 0.03 & -0.37 & & 0.95 & 0.77 \\
\hline WUEp & 0.97 & 0.48 & 0.59 & 0.72 & 0.81 & 0.77 & 0.76 & 0.88 & 0.58 & -0.81 & 0.80 & & 0.55 \\
\hline WUEs & 0.58 & 0.93 & -0.37 & 0.88 & 0.84 & 0.86 & 0.85 & 0.70 & 0.83 & -0.84 & -0.07 & 0.45 & \\
\hline
\end{tabular}

Values in boldface are significant (off-diagonal) at level of significance alpha $=5 \%$ (bilateral test).

Figures in normal font and italics represent the results of the third and fourth years of production.

Yp: irrigated DM yield; Ys: rainfed DM yield; TOL: tolerance; HM: harmonic mean; MP: mean production; GMP: geometric mean production; STI: stress tolerance index; $\mathrm{K}_{1} \mathrm{STI}$ : irrigated modified stress tolerance index; $\mathrm{K}_{2} \mathrm{STI}$ : rainfed modified stress tolerance index; Pi: superiority index; ATI: abiotic tolerance index; WUEp: irrigated water use efficiency; WUEs: rainfed water use efficiency. 
Figure 2. Three-dimensional representation of cultivars: (a) third year of production and (b) fourth year of production.

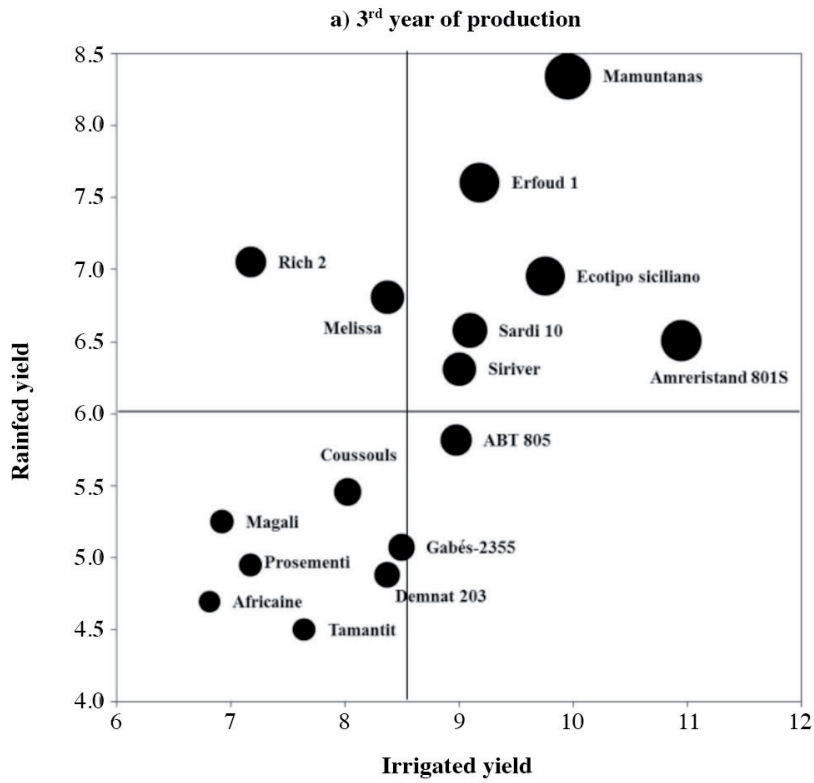

After the one-dimensional test of equality of means, it was found that the variables $\mathrm{Yp}, \mathrm{K}_{1} \mathrm{STI}$, and $\mathrm{K}_{2} \mathrm{STI}$ in the third year and variables Pi and WUEp in the fourth year were the most discriminating. Thus, the new synthetic variables of canonical functions with standardized coefficients are converted:

In the third year: $\mathrm{F} 1=6.77 \times \mathrm{Yp}-7.98 \times \mathrm{K}_{1} \mathrm{STI}+2.42 \times$ $\mathrm{K}_{2} \mathrm{STI} ; \mathrm{F} 2=1.57 \times \mathrm{Yp}-2.41 \times \mathrm{K}_{1} \mathrm{STI}+0.03 \times \mathrm{K}_{2} \mathrm{STI}$

In the fourth year: $\mathrm{F} 1=0.63 \times \mathrm{WUEp}-0.45 \times \mathrm{Pi}$; $2=$ $1.30 \times$ WUEp $+1.37 \times \mathrm{Pi}$

The Mahalanobis distance calculated between the groups showed the highest value between groups 1 and 2 in the third and fourth years of production. However, groups 1 and 3 were the closest (Table 6).

The confusion matrix for the cross-validation results provided a good ranking of individuals, $81.25 \%$ in the

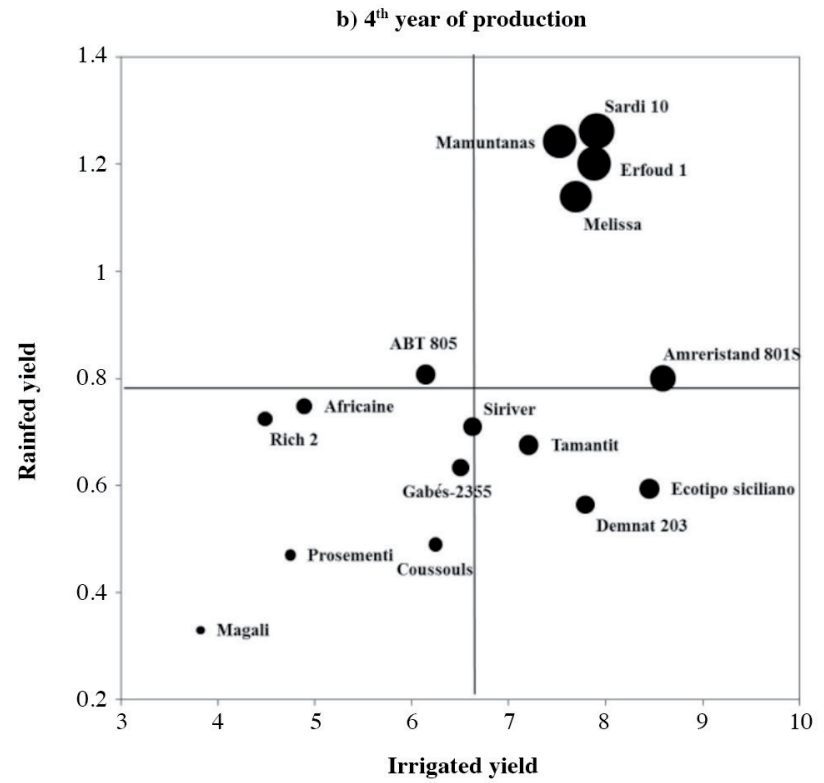

third year and $100 \%$ in the fourth year. Thus, homogeneous groups became invariable after cross-validation in the fourth year (Table 7); mean values for each variable are shown in Table 8 .

This grouping was confirmed by the characteristics of each group of cultivars. Group 3 of the third year of production and group 1 of the fourth year contained cultivars that adapt to abiotic stress (water stress and salt stress). The Italian 'Mamuntanas' and 'Ecotipo siciliano' grow well in the rainfed trial and the American 'Ameristand 801S' tolerates salinity (Annicchiarico et al., 2011). Moreover, Moroccan 'Erfoud 1' is widely adapted to drought and saline soil (Annicchiarico et al., 2013). The study conducted on cultivars, such as the ones used in our experiment, except for 'Tamantit' and

Figure 3. Plan F1 and F2 of discriminant function analysis: (a) third year of production and (b) fourth year of production.

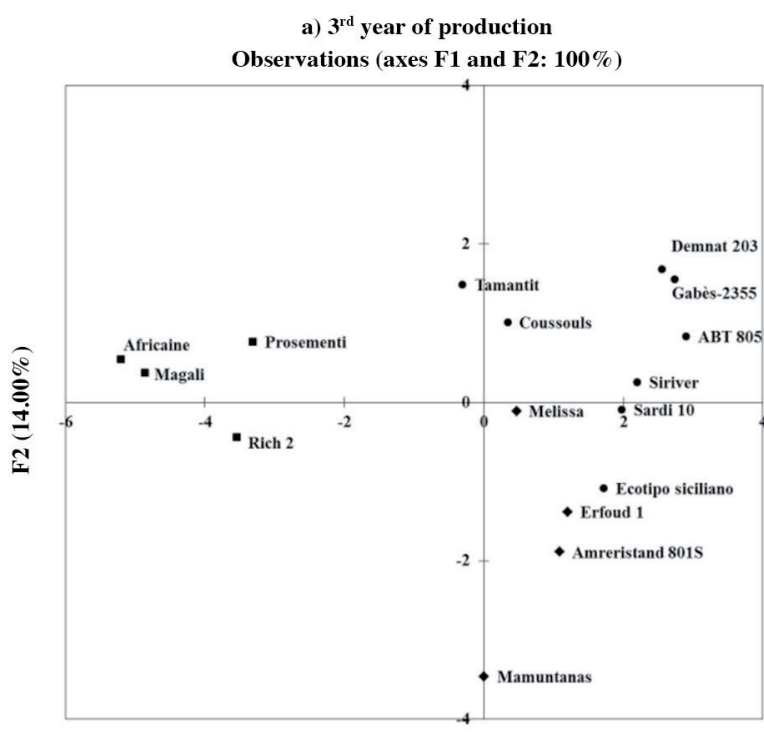

F1 $(86 \%)$

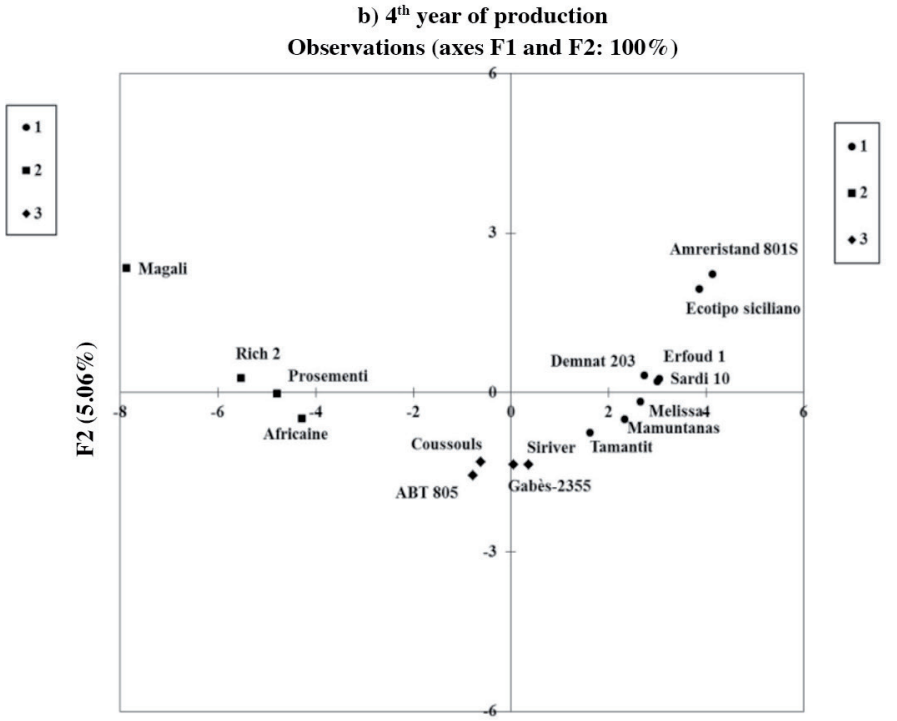

F1 $(94.94 \%)$ 
Figure 4. Ascending hierarchical classification of cultivars: (a) third year of production and (b) fourth year of production.
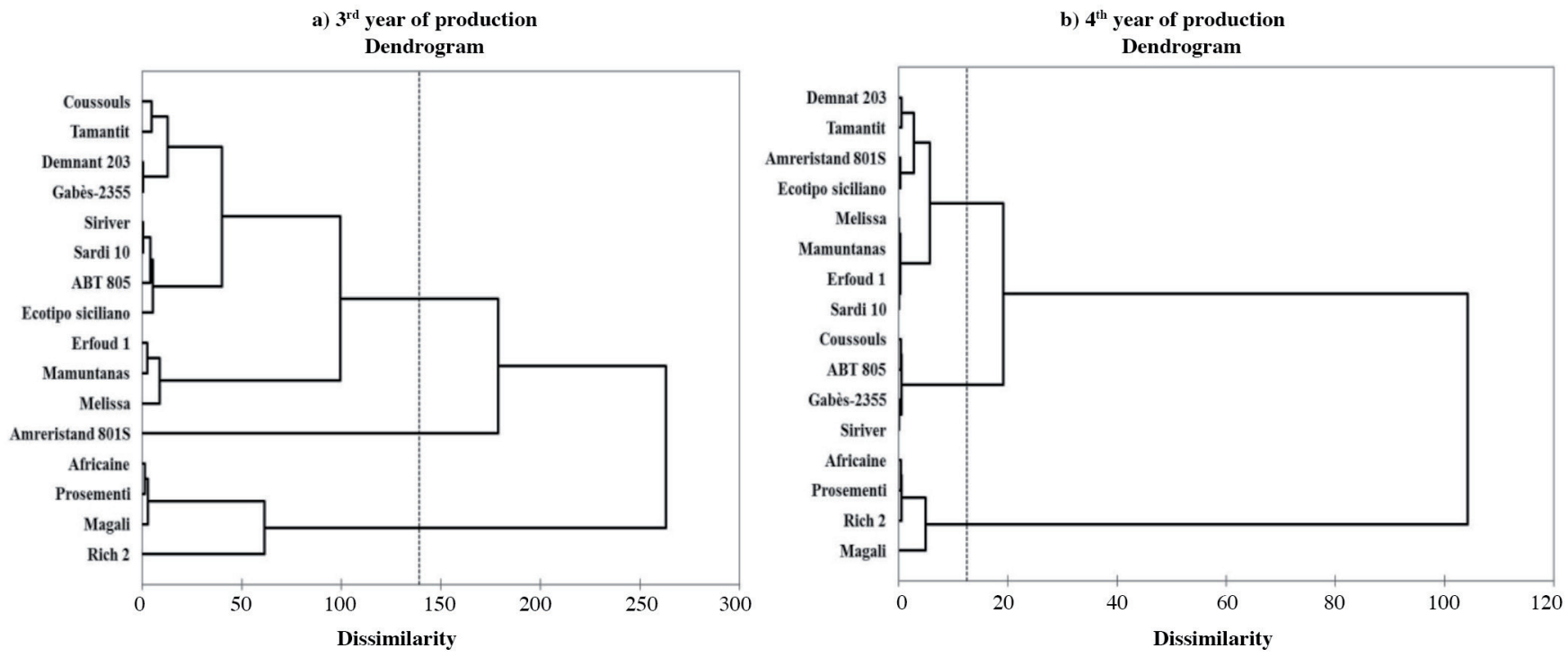

Table 5. Results of discriminant functions.

\begin{tabular}{lcccrl} 
Year & $\begin{array}{c}\text { Factor } \\
\text { axis }\end{array}$ & $\begin{array}{c}\text { Intrinsic } \\
\text { value }\end{array}$ & $\begin{array}{c}\% \\
\text { discrimination }\end{array}$ & $\begin{array}{c}\text { Bartlett } \\
\text { statistic }\end{array}$ & p level \\
\hline $3^{\text {rd }}$ & F1 & 07.57 & 86.00 & 34.86 & 0.000 \\
& F2 & 01.23 & 14.00 & 9.02 & 0.008 \\
$4^{\text {th }}$ & F1 & 14.99 & 94.94 & 43.88 & 0.000 \\
& F2 & 00.80 & 05.06 & 10.81 & 0.007 \\
\hline
\end{tabular}

most profitable and 'Erfoud 1' ranked among the top six cultivars (Annicchiarico et al., 2011).

The ANOVA of the cumulative yield in both trials of the two years of production indicated a significant genotype effect at the $5 \%$ level of significance, revealing the existence of differences in performance among tested cultivars. This analysis also showed that every trial had a similar classification of the cultivars with the best yields. Thus, 'Ameristand 801S', 'Ecotipo siciliano', 'Mamuntanas', and 'Erfoud 1' topped the rankings in the irrigated trial and were among the best in the rainfed trial (Figures 5 and 6).

\section{Survival}

'Africaine', during the first three years of production in six geographically different sites (two in Tunisia, two in Algeria, one in Italy, and one in Morocco), showed that 'Ameristand 801S' and 'Mamuntanas' were the

Plant density decreased from 127.45 plants $\mathrm{m}^{-2}$ in the first year to 11.56 plants $\mathrm{m}^{-2}$ in the fourth year of production for the rainfed trial with a survival rate of $9.10 \%$. In the irrigated trial, plant density decreased from 136.95

Table 7. Discrimination of homogeneous groups of discriminant function analysis after cross-validation.

\begin{tabular}{lll}
\hline Year & Group & \multicolumn{1}{c}{ Cultivar } \\
\hline $3^{\text {rd }}$ & G1 & ABT 805, Ameristand 801S, Tamantit, Sardi 10, Siriver, Gabès-2355, Melissa, Coussouls, and Demnat 203 \\
& G2 & Prosementi, Magali, Rich 2, and Africaine \\
$4^{\text {th }}$ & G3 & Ecotipo siciliano, Mamuntanas, and Erfoud 1 \\
& G1 & Ecotipo siciliano, Ameristand 801S, Mamuntanas, Sardi 10, Tamantit, Melissa, Erfoud 1, and Demnat 203 \\
& G2 & Prosementi, Magali, Rich 2, and Africaine \\
& G3 & ABT 805, Coussouls, Siriver, and Gabès-2355 \\
\hline
\end{tabular}

Table 8. Mean characteristics of discriminant function analysis groups after cross-validation.

\begin{tabular}{|c|c|c|c|c|c|c|c|c|c|c|c|c|c|c|}
\hline Year & Group & Yp & Ys & TOL & $\mathrm{HM}$ & MP & GMP & STI & $\mathrm{K}_{1} \mathrm{STI}$ & $\mathrm{K}_{2} \mathrm{STI}$ & $\mathrm{Pi}$ & ATI & WUEp & WUEs \\
\hline \multirow[t]{3}{*}{$3^{\text {rd }}$} & G1 & 8.67 & 5.70 & 2.97 & 6.86 & 7.18 & 7.02 & 0.69 & 0.74 & 0.66 & 3.31 & 14.76 & 1.97 & 1.78 \\
\hline & G2 & 7.02 & 5.49 & 1.54 & 6.13 & 6.25 & 6.19 & 0.54 & 0.37 & 0.48 & 6.11 & 6.45 & 1.60 & 1.69 \\
\hline & G3 & 9.61 & 7.32 & 2.30 & 8.27 & 8.46 & 8.36 & 0.97 & 1.28 & 1.47 & 1.06 & 13.73 & 2.12 & 2.13 \\
\hline \multirow[t]{3}{*}{$4^{\text {th }}$} & G1 & 7.88 & 0.93 & 6.94 & 1.65 & 4.41 & 2.68 & 0.17 & 0.23 & 0.31 & 0.22 & 2.15 & 0.81 & 0.48 \\
\hline & G2 & 4.49 & 0.57 & 3.92 & 1.00 & 2.53 & 1.58 & 0.06 & 0.03 & 0.04 & 4.38 & 0.73 & 0.46 & 0.28 \\
\hline & G3 & 6.38 & 0.66 & 5.72 & 1.19 & 3.52 & 2.04 & 0.1 & 0.09 & 0.08 & 1.33 & 1.36 & 0.65 & 0.33 \\
\hline
\end{tabular}

Yp: irrigated DM yield; Ys: rainfed DM yield; TOL: tolerance; HM: harmonic mean; MP: mean production; GMP: geometric mean production; STI: stress tolerance index; $\mathrm{K}_{1} \mathrm{STI}$ : irrigated modified stress tolerance index; $\mathrm{K}_{2} \mathrm{STI}$ : rainfed modified stress tolerance index; Pi: superiority index; ATI: abiotic tolerance index; WUEp: irrigated water use efficiency; WUEs: rainfed water use efficiency. 
to 24.27 plants $\mathrm{m}^{-2}$ with a survival rate of $17.72 \%$. The mean survival rate in the fourth year was $50.97 \%$ and $63.40 \%$ for the rainfed and irrigated trials, respectively, compared to the third year of production (Figure 7).

The decrease in rainfall in the fourth year of $32.61 \%$ (110 $\mathrm{mm})$ and $5 \%(61.3 \mathrm{~mm})$ increase in evapotranspiration led to persistent drought, which can cause changes in cultivar behavior.

Delgado (2006) reported that plant density decreased from 232 to 38 plants $\mathrm{m}^{-2}$ with a $16.37 \%$ survival rate for five years of alfalfa under rainfed conditions; this was compared to our results under irrigated conditions.

Mean regression rate in the fourth year was $49.21 \%$ for the rainfed trial and $36.12 \%$ for the irrigated trial. Alboudi (1988) obtained a mean regression rate of $37 \%$ for five alfalfa populations studied for $2 \mathrm{yr}$ under water stress.

Under rainfed conditions, 'ABT 805' and 'Rich 2' were perennial with regression rates of $23.86 \%$ and $36.54 \%$, respectively, while 'Tamantit' and 'Ameristand 801S' were the least sustainable with regression rates of $61.79 \%$ and
Figure 7. Evolution over time of plant density.

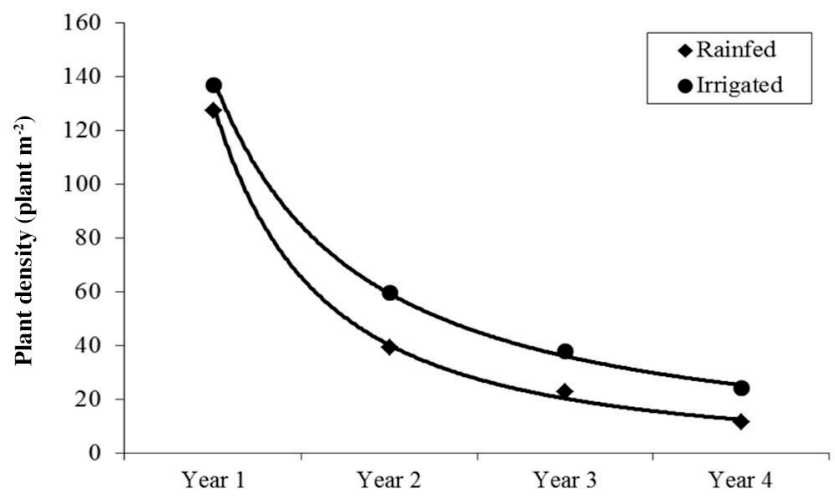

$61.76 \%$, respectively. On the other hand 'Ameristand 801S' showed the highest sustainability with a regression rate of $19.63 \%$ unlike 'Rich 2' that had the highest regression rate of $54.34 \%$ under irrigated conditions (Figure 8).

In conclusion, the study of plant density regression from the third to the fourth year showed that cultivars 'Ameristand

Figure 5. Ranking of cultivar cumulative yields for the irrigated trial with LSD5\% $\mathbf{4 . 7 5}$.

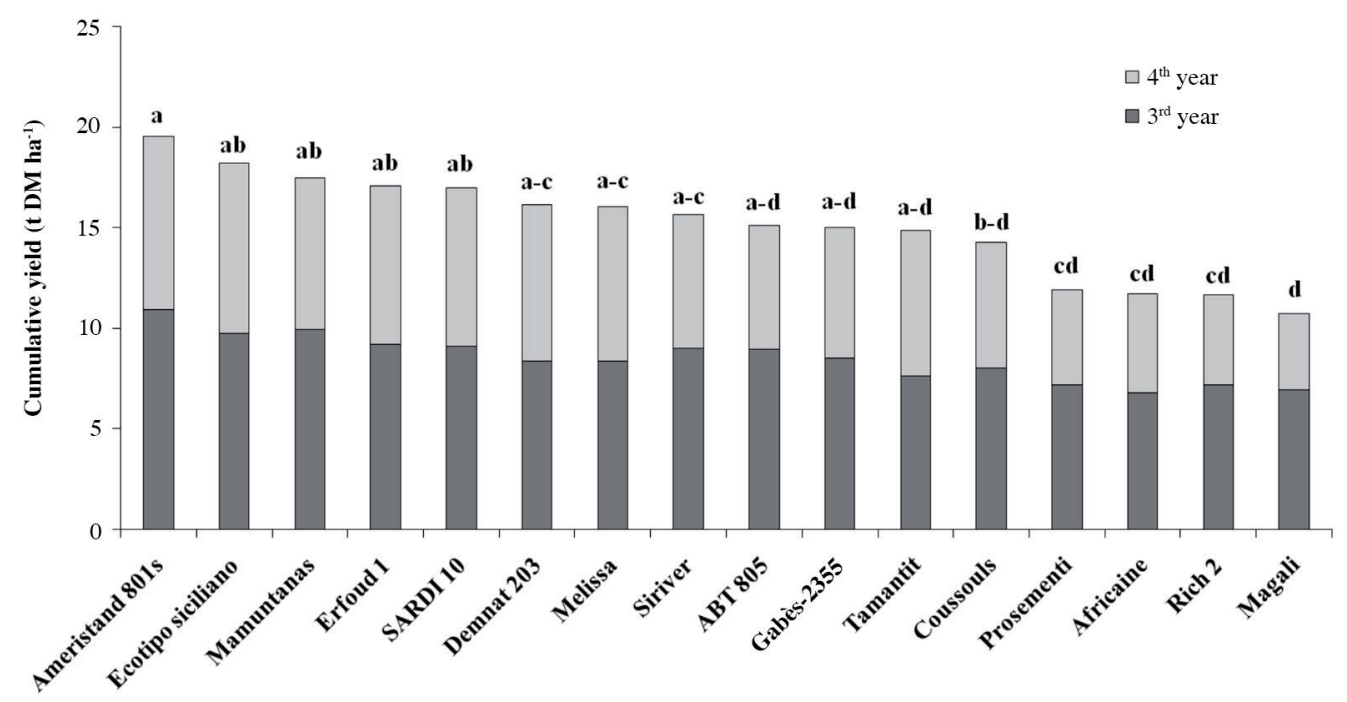

Figure 6. Ranking of cultivar cumulative yields for rainfed trial with LSD5\% $=\mathbf{2 . 3 2}$.

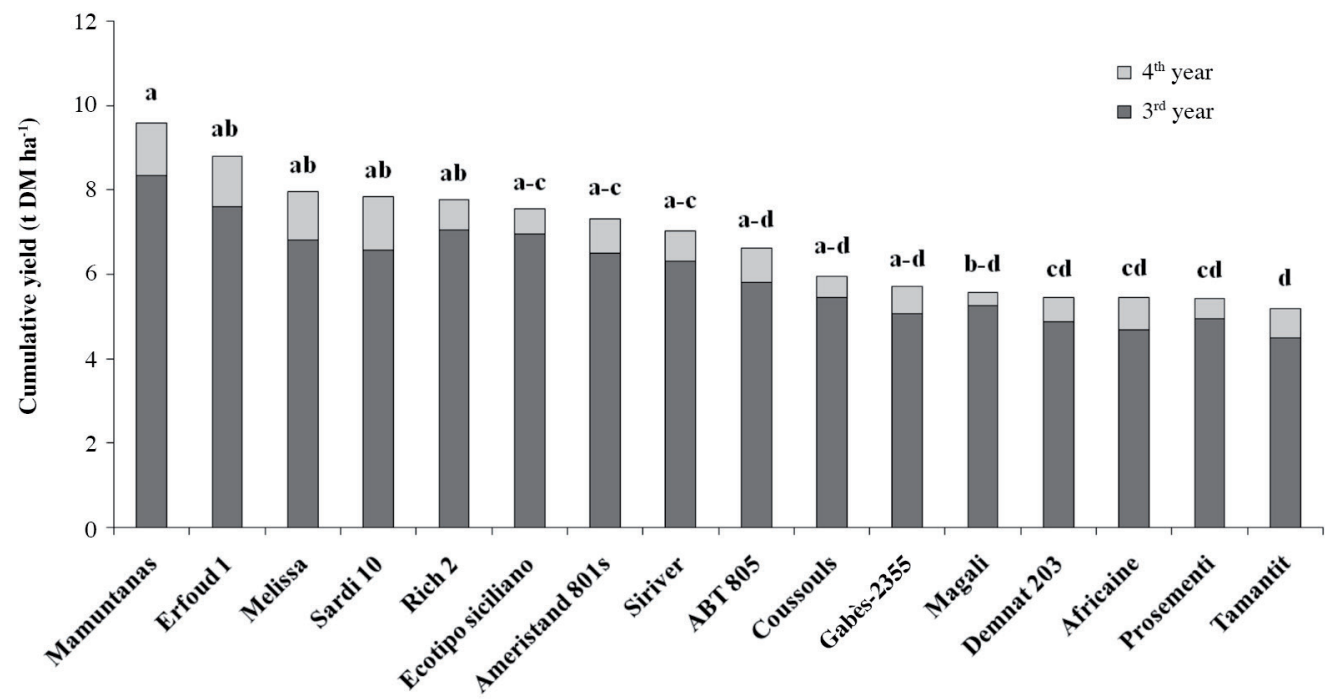


Figure 8. The regression rate $(\mathrm{Rr})$ of cultivars under irrigated and rainfed conditions.

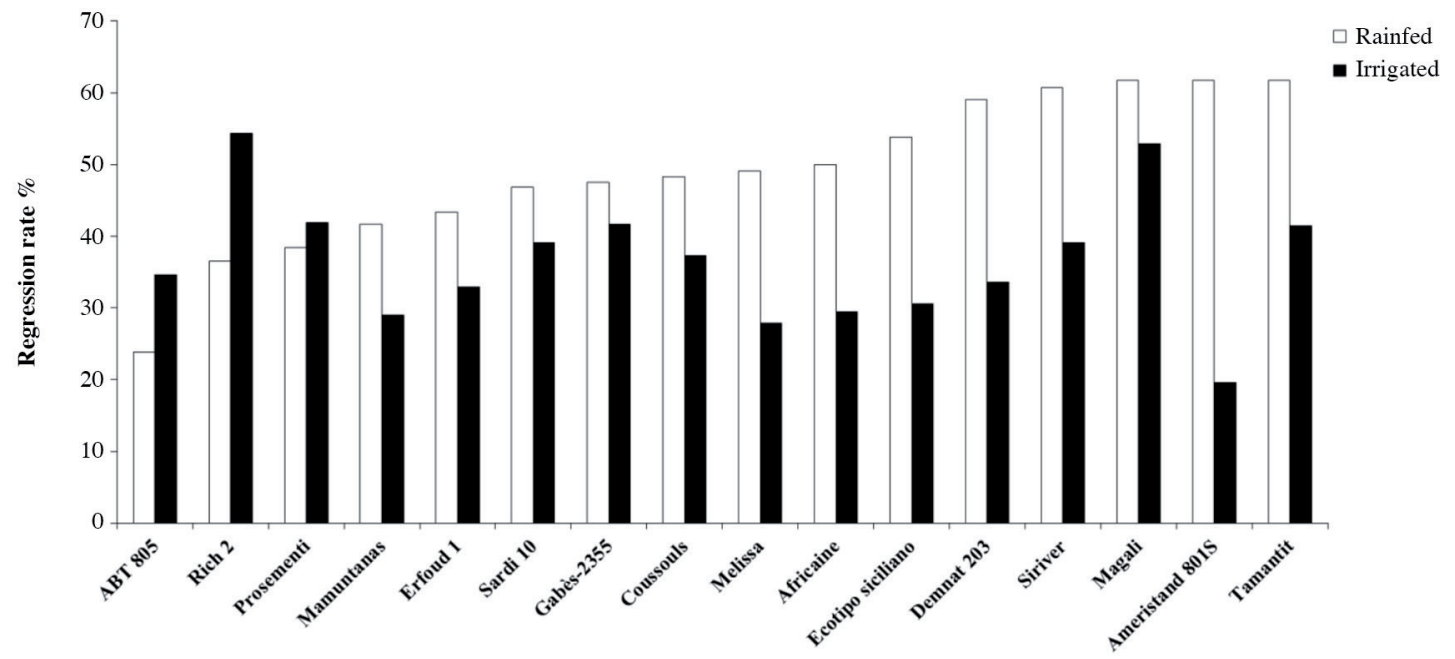

801S', 'Mamuntanas', and 'Ecotipo siciliano' were perennial in the irrigated trial while 'Erfoud1' was perennial in the rainfed trial.

\section{CONCLUSIONS}

By using the stress tolerance index, cumulative yields, and discriminant function analysis, the profitability and adaptability to drought of 'Mamuntanas', 'Ameristand 801S', 'Ecotipo siciliano', and 'Erfoud 1' are confirmed. These cultivars have the highest stress tolerance index in the third year and are among the top eight in the fourth year. The three-dimensional presentation classifies these cultivars in group A with mean yields higher than the overall mean. Discriminant function analysis reveals three homogeneous groups, which discriminated among themselves in the direction of the two factor axes by yield in the irrigated trial and modified stress tolerance index in the third year. In the fourth year, discrimination was provided by the superiority index and water use efficiency index in the irrigated trial. The ANOVA of cumulative yields over the $2 \mathrm{yr}$ classifies the cultivars with the highest yields.

The study of drought tolerance indices and plant survival makes it possible to measure performance and choose the most appropriate genetic material among the perennial alfalfa cultivars (Medicago sativa L.) tested under environmental conditions similar to those found in the Lower-Cheliff plain.

\section{REFERENCES}

Abdelguerfi, A., and M. Abdelguerfi-Laouar. 2002. Forage and pasture species: The uses in Maghreb (Algeria, Morocco, and Tunisia). FAO, Rome, Italy.

Akcura, M., and S. Ceri. 2011. Evaluation of drought tolerance indices for selection of Turkish oat (Avena sativa L.) landraces under various environmental conditions. ZemdirbysteAgriculture 98:157-166.
Alboudi, A. 1988. Contribution à l'étude des contraintes dues au régime d'exploitation et au déficit hydrique sur la dynamique de repousse et la morphologie de différents types de luzerne (Medicago sativa L.) 189 p. PhD thesis. Montpellier Academy, University of Science and Techniques of Languedoc, Lusignan, France.

Annicchiarico, P., L. Pecetti, A. Abdelguerfi, A. Bouizgaren, A.M. Carroni, T. Hayek, et al. 2011. Adaptation of landrace and variety germplasm and selection strategies for lucerne in the Mediterranean basin. Field Crops Research 120:283-291. doi:10.1016/j.fcr.2010.11.003.

Annicchiarico, P., L. Pecetti, and A. Tava. 2013. Physiological and morphological traits associated with adaptation of lucerne (Medicago sativa) to severely drought-stressed and to irrigated environments. Annals of Applied Biology 162:27-40. doi:10.1111/j.1744-7348.2012.00576.x.

Bellague, D., A. Chedjerat, A. Khedim, H.E. Khelifi, M. M'Hammedi Bouzina, B.A. Merabet, et al. 2008. Comportement et efficience d'utilisation de l'eau de quelques cultivars de luzerne pérenne dans une région semi-aride en Algérie. p. 265-268. In Porqueddu, C., and M.M. Tavares de Sousa (eds.) Sustainable Mediterranean grasslands and their multi-functions.: CIHEAM/FAO/ENMP/SPPF, Zaragoza, Spain. Options Méditerranéennes: Série A. Séminaires Méditerranéens; Nr 79. Available at http://om.ciheam.org/om/ pdf/a79/00800658.pdf (accessed December 2010).

Benabderrahim, M.A., H. Hamza, M.A. Haddad, and A. Ferchichi. 2015. Assessing the drought tolerance variability in Mediterranean alfalfa (Medicago sativa L.) genotypes under arid conditions. Plant Biosystem 149:395-403. doi:10.1080/1126350 4.2013.850121.

Bouizgaren, A., M. Farissi, C. Ghoulam, R. Kallida, M. Faghire, M. Barakate, et al. 2013. Assessment of summer drought tolerance variability in Mediterranean alfalfa (Medicago sativa L.) cultivars under Moroccan fields conditions. Archives of Agronomy and Soil Science 59:147-160. doi:10.1080/03650340.2011.606216.

Boulaine, J. 1957. Etude des sols des plaines du Chélif. 582 p. PhD Thesis. University of Algiers, Algiers, Algeria. 
Boussen, H., M. Ben Salem, A. Slama, E. Mallek-Maalej, and S. Rezgui. 2010. Evaluation of drought tolerance indices in durum wheat recombinant inbred lines. p. 79-83. Proceeding of Second International Conference on Drought Management FAO-CIHEAM, Istanbul, Turkey. 4-6 March 2010. Options Méditerrannéenes A95. Series A. Séminaires Méditerranéens n. 95. Available at http://om.ciheam.org/om/pdf/a95/00801329.pdf (accessed November 2012).

Chakherchaman, S.A., H. Mostafaei, L. Imanparast, and M.R. Eivazian. 2009. Evaluation of drought tolerance in lentil advanced genotypes in Ardabil region. Journal of Food Agriculture and Environment 7:283-288.

Clarke, J.M., R.L. De Pauw, and T.M. Townley-Smith. 1992. Evaluation of methods for quantification of drought tolerance in wheat. Crop Science 32:723-728. doi:10.2135/ cropsci1992.0011183X003200030029x.

Climate-data. 2016. Worldwide climate classification. Available at http://climate-data.org (accessed March 2016).

Dehbalaei, S., E. Farshadfar, and M. Farshadfar. 2013. Assessment of drought tolerance in bread wheat genotypes based on resistance/tolerance indices. International Journal of Agriculture and Crop Sciences 5:2352-2358.

Delgado, E. 2006. Research works on Mielgas (Medicago sativa L.) Possibilities to use for gazing and improve degraded soils in the Mediterranean region. p. 188-192. In Abdelguerfi, A. (ed.) Forage Fabaceae diversity and their symbionts: biotechnological, agronomic and environmental applications. International Workshop, Algiers, Algeria.

Durand, J.L. 2007. Les effets du déficit hydrique sur la plante: The effects of water stress on the plant: Physiological aspects. Fourrages 190:181-195.

Farissi, M., A. Bouzgaren, M. Faghire, A. Bargaz, and C. Ghoulam. 2013. Agrophysiological and biochemical proprieties associated with adaptation of Medicago sativa populations to water deficit. Turkish Journal of Botany 37:1166-1175. doi:10.3906/bot-1211-16.

Farshadfar, E., and J. Sutka. 2003. Multivariate analysis of drought tolerance in wheat substitution lines. Cereal Research Communications 31:33-40.

Fernandez, G.C.J. 1992. Effective selection criteria for assessing plant stress tolerance. p. 257-270. In Adaptation of food crops to temperature and water stress: Proceedings of an International Symposium, Taiwan, China. 13-18 August. Publication nr 93410. 531 p. Asian Vegetable Research and Development Center, Taipei, China.

Haffani, S., M. Mezni, and W. Chaibi. 2014. Agronomic performances of three vetch species growing under different drought levels. Chilean Journal of Agricultural Research 74:263272. doi: 10.406 7/S0718-58392014000300003.

Hayek, T., M. Loumerem, K. Nagaz, and M. Thabet. 2008. Growth development and dry matter yield of 16 Lucerne genotypes cultivated in south Tunisia. p. 299-302. Proceeding of $12^{\text {th }}$ Meeting of the Sub-network on Mediterranean Forage Resources of the FAO-CIHEAM, Elvas, Portugal. 9-12 April 2008. Options Méditerrannéenes A79.

Hufty, A. 2001. Introduction à la climatologie: Le rayonnement et la température, l'atmosphère, l'eau, le climat et l'activité humaine. The presses of Laval University, Quebec, Canada.

Hussain, S.S., H. Raza, I. Afzal, and M.A. Kayani. 2012. Transgenic plants for abiotic stress tolerance: Current status. Archives of Agronomy and Soil Science 58:693-721. doi:10.1080/0365034 0.2010 .540010 .
Itier, B., and B. Seguin. 2007. Drought: characterization and occurrence linked to climate and hydrology. Fourrages 190:147-162.

Khelifi, H.E., A. Khedim, B.A. Merabat, A. Benmessaoud, K. Hadj-Omar, M. Nabi, et al. 2008. Preliminary results of production and water use efficiency among perennial alfalfa cultivars (Medicago sativa) under rainfed and irrigated water regime. p. 207-210. In Porqueddu, C., and M.M. Tavares de Sousa (eds.) Sustainable Mediterranean grasslands and their multi-functions. CIHEAM/FAO/ENMP/SPPF, Zaragoza, Spain. Options Méditerranéennes: Série A. Séminaires Méditerranéens; $\mathrm{Nr} 79$. Available at http://om.ciheam.org/om/pdf/a79/00800658. pdf (accessed December 2010).

Latrach, L., M. Farissi, M. Mouradi, B. Makoudi, A. Bouizgaren, and C. Ghoulam. 2014. Growth and nodulation of alfalfarhizobia symbiosis under salinity: electrolyte leakage, stomatal conductance, and chlorophyll fluorescence. Turkish Journal of Agriculture and Forestry 38:320-326. doi:10.3906/tar-1305-52.

Lemaire, G. 2006. La luzerne: Alfalfa. Productivity and quality. p. 174-182. In Abdelguerfi, A. (ed.) forage Fabaceae diversity and their symbionts: biotechnological, agronomic and environmental applications. International Workshop, Algiers, Algeria.

Lin, C.S., and M.R. Binns. 1988. A superiority measure of cultivar performance for cultivar $\times$ location data. Canadian Journal of Plant Science 68:193-198. doi:10.4141/cjps88-018.

McDonald, M., W.S. Atkins, and BNEDER. 1990. Étude de l'avant projet détaillé des extensions de Guerouaou et de Sebkhat Benziane et du réaménagement du Bas-Cheliff. Analyse des ressources en sol, report nr I-B. Bureau National d'Étude pour le Développement Rural (BNEDER). Ministry of Hydraulics, National Agency of Realization and management Hydraulic Infrastructures for Irrigation and Drainage (AGID), Algeria.

Mauriés, M. 1994. La luzerne aujourd'hui. Editions France Agricole, Paris, France.

Moghaddam, A., J. Vollmann, W. Wanek, M.R. Ardakani, A. Raza, G. Pietsch, et al. 2012. Suitability of drought tolerance indices for selecting alfalfa (Medicago sativa L.) genotypes under organic farming in Austria. Crop Breeding Journal 2:79-89.

Mollasadeghi, V., M. Valizadeh, R. Shahryari, and A.A. Imani. 2011. Evaluation of end drought tolerance of 12 wheat genotypes by stress indices. World Applied Sciences Journal 13(3):545-551.

Moosavi, S.S., B. Yazdi Samadi, M.R. Naghavi, A.A. Zali, H. Dashti, and A. Pourshahbazi. 2007. Introduction of new indices to identify relative drought tolerance and resistance in wheat genotypes. Desert 12:165-178.

Naghavi, M.R., A. Pour Aboughadareh, and M. Khalili. 2013. Evaluation of drought tolerance indices for screening some of corn (Zea mays L.) cultivars under environmental conditions. Notulae Scientia Biologicae 5:388-393.

Öztürk, A., S. Bayram, K. Haliloglu, M. Aydin, Ö. Çaglar, and S. Bulut. 2014. Characterization for drought resistance at early stages of wheat genotypes based on survival, coleoptile length, and seedling vigor. Turkish Journal of Agriculture and Forestry 38:824-837.

Pecetti, L., A.M. Carroni, P. Annicchiarico, P. Manunza, A. Longu, and G. Congiu. 2008. Adaptation, summer survival and autumn dormancy of lucerne cultivars in a south European Mediterranean region (Sardinia). p. 471-474. In Porqueddu, C., and M.M. Tavares de Sousa (eds.) Sustainable Mediterranean grasslands and their multi-functions. CIHEAM/FAO/ENMP/SPPF, Zaragoza, Spain. Options Méditerranéennes: Série A. Séminaires Méditerranéens; $\mathrm{Nr} 79$. Available at http://om.ciheam.org/om/pdf/a79/00800699. pdf (accessed December 2010). 
PERMED. 2004. Improvement of native perennial forage plants for sustainability of Mediterranean farming systems. PERMED project-INCO-2004-509140.

Rahimi, M., H. Dehghani, B. Rabiei, and A.R. Tarang. 2013. Evaluation of rice segregating population based on drought tolerance criteria and biplot analysis. International Journal of Agriculture and Crop Sciences 5:194-199.

Rosielle, A.A., and J. Hamblin. 1981. Theoretical aspects of selection for yield in stress and non-stress environment. Crop Science 21:943-946.

Sareen, S., B.S. Tyagi, A.K. Sarial, V. Tiwiari, and I. Sharma. 2014. Trait analysis, diversity, and Genotype $\times$ Environment interaction in some wheat landraces evaluated under drought and heat stress conditions. Chilean Journal of Agricultural Research 74:135142. doi:10.4067/S0718-58392014000200002.
Sio-Se Mardeh, A., A. Ahmadi, K. Poustini, and V. Mohammadi. 2006. Evaluation of drought resistance indices under various environmental conditions. Field Crops Research 98:222-229.

Teuber, L.R., K.L. Taggard, L.K. Gibbs, M.H. McCaslin, M.A. Peterson, and D.K. Barnes. 1998. Fall dormancy. p. A-1. In Fox, C.C., L. Berberet, F.A. Gray, C.R. Grau, D.L. Jessen, and M.A. Peterson (ed.) Standard tests to characterize alfalfa cultivars. $3^{\text {rd }}$ ed. North American Alfalfa Improvement Conference (NAAIC), Beltsville, Maryland, USA.

WRB. 2015. World Reference Bas for soil resources 2014: International soil classification system for naming soils and creating legends for soils maps. World Soil Resources Reports nr 106. FAO, Rome, Italy.

Zwart, S.J., and W.G.M. Bastiaanssen. 2004. Review of measured crop water productivity values for irrigated wheat, rice, cotton and maize. Agricultural Water Management 69:115-133. 